\title{
Insetos associados ao cultivo do cogumelo comestível Lentinula edodes (Berk.) Pegler (Agaricales: Agaricaceae) no Brasil
}

\section{Insects associated with edible mushroom Lentinula edodes (Berk.) Pegler (Agaricales: Agaricaceae) cultivation in Brazil}

\author{
Marliton R. Barreto ${ }^{1}$; Noemia K. Ishikawa ${ }^{2}$; Ulisses B. Albino ${ }^{3}$; \\ Gisele M. Andrade-Nobrega ${ }^{2}$; Luzia D. Paccola-Meirelles ${ }^{2}$
}

\section{Resumo}

O cultivo de Lentinula edodes apresenta-se em crescente expansão no Brasil. Um dos problemas enfrentados pelos produtores é o ataque de insetos, tanto no substrato de crescimento do micélio, como durante o processo de formação do basidiocarpo. Este trabalho teve por objetivo fazer um levantamento preliminar dos insetos associados ao cultivo do shiitake. Deste modo, foram realizadas coletas de insetos invasores de culturas, por meio do uso de puçá e sugadores, em Londrina (PR), Rolândia (PR), Nova Friburgo (RJ), Sorocaba (SP) e Viçosa (MG). Como resultado, foram encontrados insetos das ordens Coleóptera (Bostrichidae, Staphilinidae e Dermestidae), Diptera (Calliphoridae), Himenoptera (Formicidae) e Lepidoptera (Stenomatidae).

Palavras-chave: Insecta, Shiitake, Incidência Natural, Pragas.

\begin{abstract}
Lentinula edodes has adapted itself well to the Brazilian climate and its cultivation techniques are accessible to small and large producers. As with any other crop, the shiitake faces insect and pest attack problems, both during the mycelia colonization period in the substrate and during the basidiocarp formation. There is no report up to now of the pests that may attack in the crop in Brazil. Consequently, this study was carried out as a preliminary survey of the insects associated with shiitake cultivation both in the growing substrate and in the fruiting bodies. The samples were taken from properties situated in Londrina (PR), Rolândia (PR) Nova Friburgo (RJ) Sorocaba (SP) and Viçosa (MG). As a result, insects from the orders Coleoptera (Bostrichidae, Staphilinidae and Dermestidae), Diptera (Calliphoridae), Himenoptera (Formicidae) and Lepidoptera (Stenomatidae), were found.
\end{abstract}

Key words: Insect, Shiitake, Natural Incidence, Pest.

Biólogo, Dr. Universidade Federal do Paraná, Departamento de Ciências Biológicas. C.P. 19020, CEP: 81531-990, Curitiba-PR, e-mail: barreto@cnpso.embrapa.br

2 Bióloga, Profa. Dra. Universidade Estadual de Londrina, Departamento de Biologia Geral, C.P. 6001, CEP: 86051-990, Londrina-PR.

Biólogo, Dr. Universidade Estadual de Londrina, Departamento de Microbiologia, C.P. 6001, CEP: 86051-990, Londrina, Pr. 
Lentinula edodes (Berkley) Pegler is an edible mushroom that has been used in oriental cooking for centuries. Popularly known as Shiitake, its cultivation and consumption have become popular in various countries and presently it is the third most cultivated mushroom in the world (CHANG et al., 1995) and the most commercially important mushroom grown on wood (TOKIMOTO et al., 1998). Its flavor and nutritional properties distinguish this basidiomycete. Its therapeutic properties have been emphasized since the 1960s and have been described and discussed in revisions by Breene (1990), Przybylowicz e Donoghue (1990), Jong e Birmingham (1993).

L. edodes has adapted it self well to the Brazilian climate and the cultivation techniques are accessible to small and large producers. Cultivation is concentrated mainly in the South and Southeastern regions of Brazil, where this crop has become the main commercial income source in the properties of some growers. As with any other crop, the shiitake faces insect and pest attack problems, both during the mycelia colonization period in the substrate and during the basidiocarp formation (fructification). Success in mushroom cultivation, apart from the technical aspects, depends on many interacting factors, both biotic and abiotic, which affect yield and quality. Biotic factors, such as pests and pathogens, often produce the most obvious symptoms although some abiotic factors, such as temperature and water, can show effects as obvious as those produced by organisms. The most commonly encountered biotic causes of disorders are bacteria, fungi, nematodes, mites and insects and have already been reported in $L$. edodes cultivation in other countries (ITO, 1978; QUIMIO et al., 1990). The diversity and complexity of the associations of fungi and insects are poorly understood. Many large and evolutionarily successful groups of insects owe much of their proliferation to fungal food sources, and fungi frequently profit from insects with regard to spore dispersal and habitat provision, and even as nutrient sources (WHEELER and BLACKWELL, 1984).

Identification of the pathogen is important and necessary before beginning a disease or pest control program, along with biological knowledge of the pathogen, so that access and dispersion in the crop contribute to a more efficient control. Hygiene in the crop locality contributes to better control in any situation.

The Brazilian producer has, for economic reasons, to adopt more rustic production technology that favors pest and disease attacks. The incidence of insect pests has been one of the problems that affect shiitake cultivation in Brazil (ISHIKAWA et al, 1997). There is no report up to now of the pests which may attack the crop in Brazil, and thus this study was carried out as a preliminary survey of the insects associated with shiitake cultivation both in the growing substrate and in the fruiting bodies. Samples were taken from the substrate (Eucalyptus spp. logs) and the mushroom itself using an insect net and suction. The samples were taken on properties situated in Londrina (PR), Rolândia (PR), Nova Friburgo (RJ), Sorocaba (SP) and Viçosa (MG). After collection and packaging, the insects were taken to the Biology Laboratory for Insects at the Federal University of Viçosa, in Viçosa, (MG), where they were identified according to Stehr, (1991); DuPorte, (1977); Borror and Delong, (1988; Costa et al. (1988). Table 1, lists some insects identified in the survey, which damage shiitake cultivation and commercialization in Brazil.

Table 1 - Insects collected from Lentinula edodes crops in Brazil.

\begin{tabular}{llll}
\hline $\begin{array}{l}\text { Order } \\
\text { Hymenoptera }\end{array}$ & Family & Structures & Stage found \\
& Formicidae & Growing substrate & Adult \\
\hline Coleoptera & Bostrichidae & Growing substrate and gills & larva and adult \\
\hline & Staphilinidae & primordium and gills & Adult \\
\hline & Dermestidae & On the mushroom cap & Adult \\
\hline Diptera & Calliphoridae & Mushroom cap and gills & larva and adult \\
\hline Lepidoptera & Stenomatidae & Mushroom cap and gills & Caterpillar \\
\hline
\end{tabular}

Some isolated insect orders in crops in other countries are described in the literature and the most frequent are listed in Table 2. The commercial value of the shiitake fruitbodies in Japan is lost or at least lowered if they are damaged by the collembolan, Hypogastrura retucykata (TSUNEDA and ARITA, 1982) and by the Dacne japonica and Dacne picta beetles (Ohya, 1995). There is agreement among the 
orders reported with those described here, although they differ for the families. Thus surveying must continue to effectively understand the role of these insects in the crop and their efficient control.

Table 2 - Main pests described in Lentinula edodes cultivation.

\begin{tabular}{|c|c|c|c|c|}
\hline $\begin{array}{l}\text { Order } \\
\text { Collembola }\end{array}$ & $\begin{array}{l}\text { Family } \\
\text { Entomobrydae }\end{array}$ & $\begin{array}{l}\text { Structure } \\
\text { Mushroom } \\
\text { and mycelia }\end{array}$ & $\begin{array}{l}\text { Stage } \\
\text { Larva }\end{array}$ & $\begin{array}{l}\text { Reference } \\
\text { Thomas,1939; } \\
\text { Tsuneda \& Arita, } \\
1982\end{array}$ \\
\hline \multirow[t]{4}{*}{ Coleoptera } & Termitidae & $\begin{array}{l}\text { Growth } \\
\text { substrate }\end{array}$ & Adult & $\begin{array}{l}\text { Przybylowicz \& } \\
\text { Donoghue, } 1990\end{array}$ \\
\hline & Scolytidae & $\begin{array}{l}\text { Growth } \\
\text { substrate }\end{array}$ & Larva and adult & $\begin{array}{l}\text { Przybylowicz \& } \\
\text { Donoghue, } 1990\end{array}$ \\
\hline & Erotylidae & Mushroom & Larva and adult & $\begin{array}{l}\text { Ohya, 1992; } \\
\text { Savary, 1995, Ohya } \\
\text { et al, 1995; Sato et } \\
\text { al, 1998 }\end{array}$ \\
\hline & Cerambycidae & $\begin{array}{l}\text { Growth } \\
\text { substrate }\end{array}$ & Larva and adult & $\begin{array}{ll}\text { Onagamitsu } & \& \\
\text { Kaneko, 1990 } & \\
\end{array}$ \\
\hline \multirow[t]{2}{*}{ Diptera } & Mycetophilidae & Mushroom & $\begin{array}{l}\text { Larva and adult } \\
\end{array}$ & $\begin{array}{l}\text { Sasakawa, } 1992 \\
\end{array}$ \\
\hline & Sciaridae & Mushroom & Larva and adult & Sasakawa, 1992 \\
\hline
\end{tabular}

\section{Referências}

BORROR, D. J.; DeLONG, D. M. Introdução ao Estudo dos Insetos. São Paulo: E. Blucher, 1988, 653p.

BREENE, W.M. Nutritional and medicinal value of Specialty mushrooms. 1990.In:NATIONAL SYMPOSIUM AND TRADE SHOW, 1990, St. Paul. According... St. Paul: University of Minnesotta,,1990, p.87-112.

CHANG, S.T.; KWAN, H.S.; KANG, Y.N. Collection, characterization and utilization of germ plasm of Lentinula edodes. Canadian Journal of Botany, Ottawa, v.73, p.955961. 1995.

COSTA, C.; VANIN, A. S.; CASARI-CHEN, S. A. Larvas de Coleoptera do Brasil. São Paulo: USP/Museu de Zoologia, $1988.379 \mathrm{p}$.

DuPORTE, E. M. Manual of insect morphology. New York: R.E. Krieger, 1977, 224 p.

ISHIKAWA, N. K.; BARRETO, M. R..; ALBINO, B. U.; PACCOLA-MEIRELLES,L.D. Insetos Associados ao cultivo do cogumelo comestível Lentinula edodes (Berk) Pegler (Agaricales:Agaricaceae). XVI Congresso Brasileiro de Entomologia, Março de 1997. Salvador, BA.

ITO, T. Cultivation of Lentinus edodes. In: CHANG, S.T., HAYES W. A. (Ed.). The biology and cultivationof edible mushrooms. New York: Academic Press, 1978, p.461-473.

JONG, S.C; BIRMINGHAM, J.M. Medicinal and therapeutic value of the shiitake mushroom, Advances in Applied Microbiology, San Diego, v.39, p.153-184, 1993.
OHYA, E. The bionomics of Dacne japonica (Coleoptera: Erotylidae), a pest of the shiitake mushroom (Lentinus edodes [Lentinula edodes]). Journal of the Japanese Forestry Society, Tokyo, v.74,n.4, p.331-336, 1992.

OHYA, E.; SATO, H.; SATO, T. Hibernation and Aestivation Sites of Dacne japonica and D. picta (Coleoptera: Erotylidae) In: A Cultivated Field of Shiitake Mushrooms (Lentinus edodes). Journal of the Japanese Forestry Society, Tokyo, v.77, n.4, p.366-369, 1995.

ONAGAMITSU, J.; KANEKO, S. Studies on Seasonal Occurrence and Control of Moechotypa diphysis (Pascoe) (Coleoptera: Cerambycidae) in Fukuoka Prefecture. Bulletin of Fukuoka ken Forest Experiment Station, v.37, p.1-58, 1990.

PRZYBYLOWICZ, P.; DONOGHUE, J. Shiitake Growers Handbook: the art and science of mushroom cultivation. New York: Kendall Hunt Publishing, 1990.217p.

QUIMIO, T.H.; CHANG, S.T.; ROYSE, D. J. Technical guidelines for mushroom growing in the tropics. Rome: FAO Plant production and protection paper, 1990.155p.

SASAKAWA, M. Two New Fungus Gnats (Diptera: Mycetophilidae and Sciaridae) Associated with Cultivated Shiitake Mushroom. Applied Entomology and Zoology, Tokyo, v.27, n.4, p.571-574, 1992.

SATO, T.; NAKAMUTA, K.; NAKASHIMA, T. Behavioral Response of Dacnepicta (Coleoptera: Erotylidae) to Different Growing Stages of the Shiitake Mushroom, Lentinula edodes. Applied Entomology and Zoology, v. 33, n. 2, p. 223-226. 1998.

SAVARY,W.E. Dacne picta Crotch: A Recently Introduced Pest of Stored, Drie Shiitake Mushrooms (Coleoptera: Erotylidae). Pan PacificEntomologist. v. 71, n. 2, p. 87-91. 1995.

STEHR, F. W. Immature Insects. Iowa: Kendall/Hunt Publishing .1991.v.2, 975 p.

THOMAS, C.A. The animals associated with Edible Fungi. Journal New York Entomological Society, New York, v.57, p.11-37, 1939.

TOKIMOTO, K.; FUKUDA, M.; TSUBOI, M. Effect of the Physical Properties of Lentinula edodes Bedlogs on Fruiting body production. Mycoscience, Tokyo, v.39, p.217-219, 1998.

TSUNEDA, A.; ARITA, T. Mycophagous activity of a collembolan Insect, Hypogastrura Reticulata Borner on Shiitake Bed-Logs. Reports of The Tottori Mycological Institute (Japan), Tottori,v.20, p.70-75, 1982.

WHEELER, Q.; BLACKWELL, M. Fungus-Insect relationships: pespectives in ecology and evolution. New York: Columbia University, 1984. 514p. 
